\title{
PENGARUH KEPUASAN KERJA DAN LINGKUNGAN KERJA TERHADAP ORGANIZATIONAL CITIZENSHIP BEHAVIOR KARYAWAN PT. PERKEBUNAN NUSANTARA XIV
}

\author{
Andi Hendro 1) \\ 1) Dosen Program Studi Manajemen STIE Tri Dharma Nusantara \\ Muh Ilham Alimuddin 2) \\ 2) Dosen Program Studi Manajemen STIE Tri Dharma Nusantara \\ Alamat: JI. Kumala II Kampus STIE TDN Makassar \\ Email: iam.philosophia@gmail.com
}

\begin{abstract}
This study aims to determine the effect of work and work environment on organizational citizenship behavior at PT. Perkebunan Nusantara XIV. Sources of data in this study are primary data and secondary data as well as data collection methods with interviews and questionnaires. The data analysis method used was simple multiple linear regression analysis. The results showed that work goals and work environment had a positive and significant effect on organizational citizenship behavior at PT. Perkebunan Nusantara XIV.
\end{abstract}

Keywords: Job satisfaction, work environment, organizational citizenship behavior

\section{PENDAHULUAN}

\begin{abstract}
Perusahaan dalam menghadapi persaingan bisnis dan perkembangan teknologi yang cepat saat ini, dituntut pula untuk memiliki sumber daya manusia yang unggul dan loyal terhadap perusahaan. Perusahaan harus mempersiapkan peran yang lebih besar lagi dalam pengelolaan sumber daya manusia agar karyawan merasa puas dalam bekerja sehinga mendukung kelancaran diberbagai fungsi organisasi. PT. Perkebunan Nusantara XIV Pabrik Gula takalar merupakan salah satu perusahaan gula di Sulawesi Selatan yang Berlokasi di Desa Parappunganta Kota Takalar. Perusahaan ini menjadi penopang produksi gula yang ada di Sulawesi Selatan sehingga membutuhkan karyawan yang banyak, serta beberapa level jabatan yang sangat kompleks dengan karakter pekerja yang tentunya berbeda satu sama lain. Sebagai
\end{abstract}

perusahaan yang cukup berkembang maka Pabrik Gula Takalar harus menunjukkan eksistensinya dengan tetap mempertahankan kinerja yang baik selama proses produksinya, sehingga produktivitas kerja akan maksimal.

Organisasi akan berhasil apabila karyawan tidak hanya melakukan tugas utamanya saja, namun melakukan tugas ekstra diluar dari pekerjaannya seperti mau bekerja sama, tolong menolong, , serta mau menggunakan waktu kerjanya dengan efektif. Perilaku ini lah yang diebut Organizational Citizenship Behavior.

Karyawan yang memiliki sikap Organizational Citizenship Behavior. cenderung akan memberikan kontribusi nyata, semata- mata hanya untuk kemajuan perusahaan tanpa mengharapkan reward atau imbalan apapun dari perusahaan. Organizational Citizenship Behavior. salah satunya dapat meningkatkan efektivitas perusahaan, meningkatkan produktivitas kerja, serta 
membantu karyawan untuk bisa beradaptasi dengan karyawan lain maupun lingkungan sekitar. Peningkatan Organizational Citizenship Behavior bergantung terhadap kepuasan kerja yang dirasakan oleh karyawan, apabila karyawan memiliki kepuasan kerja yang baik maka akan memberikan pengaruh pada kinerja mereka dalam organisasi. (Swaminathan, 2013).

Lingkungan kerja dikatakan baik atau sesuai apabila manusia dapat melaksanakan kegiatan secara optimal, sehat, aman dan nyaman. Lingkungan kerja yang kurang baik dapat menuntut tenaga kerja dan waktu yang lebih banyak dan tidak mendukung diperolehnya rancangan sistem kerja yang efisien (Sedarmayanti, 2017). Menurut Sukmawati dan Surachman (2013) evaluasi pikologis terhadap lingkungan kerja oleh individu mulai menjadi makin penting bagi perilaku ekstra peran dari karyawan, yang selanjutnya bisa menjelaskan apa yang menjadi kebutuhan individu di tempat kerja.

Kepuasan kerja yang terlihat pada karyawan PT. Perkebunan Nusantara XIV mereka kadang memiliki interaksi dengan rekan sekerja dan atasan kurang baik dan ada beberapa karyawan tidak memenuhi standar kinerja yang ditetapkan. Lingkungan kerja PT. Perkebunan Nusantara XIV menjadi perhatian peneliti dikarenakan perusahaan ini termasuk perusahaan yang lama, fasilitas dan kondisi perusahaan sudah mulai usang. Karyawan yang bekerja di perusahaan ini memiliki perilaku yang suka membantu rekan kerja ketika menghadapi kesulitan dalam mengerjakan pekerjaaanya, hal ini terjadi karena diantara karyawan memiliki ikatan emotional dan menganggap rekan kerjanya seperti saudara sendiri.

Tujuan penelitian ini adalah untuk menganalisis pengaruh kepuasan kerja dan lingkungan kerja terhadap Organizational Citizenship Behavior karyawan PT. Perkebunan Nusantara XIV.

\section{LANDASAN TEORI}

\section{Kepuasan Kerja}

Robbins (2015) mengemukakan bahwa kepuasan kerja adalah sebagai suatu sikap umum seorang individu terhadap pekerjaannya. Pekerjaan menuntut interaksi dengan rekan sekerja dan atasan, mengikuti aturan dan kebijakan organisasi, memenuhi standar kinerja, hidup pada kondisi kerja yang sering kurang ideal, dan hal serupa lainnya. Ini berarti penilaian (assesment) seorang karyawan terhadap puas atau tidak puasnya dia terhadap pekerjaan merupakan penjumlahan yang rumit dari sejumlah unsur pekerjaan yang diskrit (terbedakan dan terpisahkan satu sama lain). Menurut Sutrisno (2012), kepuasan kerja adalah sikap karyawan terhadap pekerjaannya yang berhubungan dengan situasi kerja kerja sama antar karyawan, imbalan yang diterima dalam kerja, dan hal-hal yang menyangkut faktor fisik dan psikologis. Sedangkan menurut Colquitt et al., (2013) terdapat beberapa indikator kepuasan kerja, yaitu: 1) Gaji. 2) Promosi 3) Pengawasan (supervisi). 4) Rekan kerja. 5) Pekerjaan itu sendiri. 6) Altruism. 7) Status. 8) Lingkungan.

\section{Lingkungan Kerja}

Sedarmayanti

mengungkapkan bahwa "lingkungan kerja adalah keseluruhan alat perkakas dan bahan yang dihadapi, lingkungan sekitarnya dimana seseorang bekerja, metode kerjanya, serta pengaturan kerjanya baik sebagai perseorangan maupun sebagai kelompok". Menurut Nitisemito (2002) mengemukakan "lingkungan kerja adalah segala yang ada di sekitar para pekerja yang dapat mempengaruhi dirinya dalam menjalankan tugas yang dibebankan". 
Menurut Sedarmayanti (2012) bahwa secara garis besar, jenis lingkungan kerja terbagi menjadi dua yakni, lingkungan kerja fisik dan lingkungan kerja non fisik. Lingkungan kerja fisik adalah semua keadaan berbentuk fisik yang terdapat di sekitar tempat kerja yang dapat mempengaruhi karyawan baik secara langsung maupun secara tidak langsung. Lingkungan kerja fisik dapat dibagi dalam dua kategori, yakni: 1) Lingkungan yang langsung berhubungan dengan karyawan, seperti: pusat kerja, kursi, meja, dan sebagainnya. 2) Lingkungan perantara atau lingkungan umum dapat juga di sebut lingkungan kerja yang mempengaruhi kondisi manusia, misalnya: temperatur, kelembapan, sirkulasi udara, pencahayaan, kebisingan, getaran mekanis, bau tidak sedap, warna dan lainlain. 32 Untuk dapat memperkecil pengaruh lingkungan fisik terhadap karyawan maka langkah pertama adalah harus mempelajari manusia, baik mengenai fisik dan tingkah lakunya maupun mengenai fisiknya, kemudian digunakan sebagai dasar memikirkan lingkungan fisik yang sesuai. Lingkungan kerja non fisik adalah semua keadaan yang terjadi yang berkaitan dengan hubungan kerja, baik hubungan dengan atasan maupun hubungan dengan sesama rekan kerja, ataupun hubungan dengan bawahan. Lingkungan non fisik ini juga merupakan kelompok lingkungan kerja yang tidak bisa diabaikan.

\section{Organizational Citizenship Behavior}

Menurut Robbins (2015), organizational citizenship behavior adalah perilaku individu atau perseorangan yang sukarela dan bukan bagian dari syarat formal pekerjaan, tetapi dapat meningkatkan fungsi efektif organisasi. Sedangkan Menurut Organ et.al. (2015) organizational citizenship behavior adalah perilaku individu yang mempunyai kebebasan untuk memilih, yang secara tidak langsung atau tidak secara eksplisit dikaitkan dengan sistem reward, dan memberi kontribusi pada efektivitas dan efisiensi fungsi organisasi.

Podsakoff et al. (2000) yang mengungkapkan bahwa organizational citizenship behavior dapat memengaruhi performa organisasi. Organizational citizenship behavior juga sering diartikan sebagai perilaku yang melebihi kewajiban formal (ekstra role) yang tidak berhubungan dengan kompensasi langsung. Artinya, seseorang yang memiliki organizational citizenship behavior tinggi tidak akan dibayar dalam bentuk uang atau bonus tertentu, namun organizational citizenship behavior lebih kepada perilaku.

Terdapat lima dimensi organizational citizenship behavior yaitu (Organ \& Lingl, 1995; Organ, 2015): 1) Altruism, perilaku membantu rekan kerja yang menghadapi kesulitan yang berkaitan erat dengan tugas operasional organisasi tanpa ada paksaan. 2) Conscuentiousness, perilaku yang ditunjukkan melebihi syarat minimal yang dikehendaki perusahaan, seperti hadir lebih awal, memanfaatkan waktu kerja dengan maksimal. 3) Sportmanship, perilaku positif terhadap organisasi, dengan memberikan toleransi atau tidak mengeluh ataupun menuntut terhadap kondisi yang kurang ideal dalam organisasi. 4) Courtessy, perilaku menjaga hubungan baik dengan sesama rekan kerja, mencegah konflik supaya terhindar dari masalah interpersonal. 5) Civic Virtue, perilaku yang mencerminkan turut serta bertanggung jawab dan berpartisipasi pada keberlangsungan organisasi.

\section{Hipotesis}

Luthans (2006) mendefinisikan kepuasan kerja sebagai hasil dari persepsi karyawan mengenai seberapa baik pekerjaan yang dilakukannya memberikan hal yang dinilai penting. 
Peningkatan organizational citizenship behavior bergantung terhadap kepuasan kerja yang dirasakan oleh karyawan, apabila karyawan memiliki kepuasan kerja yang baik maka akan memberikan pengaruh pada kinerja mereka dalam organisasi. (Swaminathan, 2013). Peneliti Rohayati Ai (2014), Nurhayati, et al. (2016), Waspodo, et al, (2019) menemukan bahwa ada pengaruh positif dan signifikan kepuasan kerja terhadap organizational citizenship behavior.

Menurut Sukmawati dan Surachman (2013) evaluasi pikologis terhadap lingkungan kerja oleh individu mulai menjadi makin penting bagi perilaku ekstra peran organizational citizenship behavior dari karyawan, yang selanjutnya bisa menjelaskan apa yang menjadi kebutuhan individu di tempat kerja. Febytama (2018) Nurhayati, et al. (2016), Waspodo, et al (2019) menemukan bahwa ada pengaruh positif dan signifkan lingkungan terhadap organizational citizenship behavior.

Berdasarkan hasil penelitian tersebut maka dapat ditarik hipotesis bahwa: H1 diduga bahwa kepuasan kerja berpengaruh positif dan signifikan terhadap organizational citizenship behavior karyawan PT. Perkebunan Nusantara XIV. H2 diduga bahwa lingkungan kerja berpengaruh positif dan signifikan terhadap organizational citizenship behavior PT. Perkebunan Nusantara XIV. H3 diduga bahwa kepuasan kerja dan lingkungan kerja secara bersama-sama berpengaruh positif dan signifikan terhadap organizational citizenship behavior PT. Perkebunan Nusantara XIV.

\section{HASIL DAN PEMBAHASAN}

\section{Hasil Penelitian}

\section{Uji validitas}

Dari 10 instrumen variabel kepuasan yang diujicobakan, ternyata menunjukkan bahwa semua butir instrumen tersebut dinyatakan valid (sig. $<0.05$ ) atau $r$ hitung lebih besar dari 0,208). Dari 10 instrumen variabel lingkungan yang diuji cobakan, ternyata menunjukkan bahwa semua butir instrumen tersebut dinyatakan valid (sig. $<0.05)$ rhitung lebih besar dari 0,208). Dari 10 nomor instrumen variabel organizational citizenship behavior yang diuji cobakan, ternyata menunjukkan bahwa semua butir instrumen tersebut dinyatakan valid (sig.<0.05), rhitung lebih besar dari 0,208)

\section{Uji realibilitas}

Uji realibilitas dimaksudkan untuk mengetahui konsistensi instrumen. Semua instrumen dikatakan reliabel atau mempunyai tingkat kepercayaan yang tinggi, jika instrumen tersebut memberikan hasil yang tetap. Ini berarti bahwa instrumen dikatakan reliabel apabila diuji cobakan pada subyek lain dan dalam waktu yang lain pula akan mempunyai hasil yang sama. Hasil uji realibilitas dari masing-masing variabel dapat dilihat pada Tabel 1 berikut.

Tabel 1: Hasil Uji Realibilitas

\begin{tabular}{clcc}
\hline NO. & \multicolumn{1}{c}{ Variabel } & Cronbach Alpha & Limit \\
\hline 1 & X1 (Kepuasan) & 0,618 & 0,6 \\
2 & X2 (Lingkungan) & 0,725 & 0,6 \\
3 & Y (OCB) & 0,77 & 0,6 \\
\hline
\end{tabular}

Sumber : Data diolah 2021 
Berdasarkan hasil uji realibilitas menunjukkan bahwa semua variabel realibel, karena nilai Cronbach Alpha melebihi dari 0,60 .

\section{Analisis regresi linear sederhana}

\begin{tabular}{ccccccc}
\hline $\begin{array}{c}\text { Tabel 2: Pengaruh Kepuasan Kerja terhadap Organizational Citizenship } \\
\text { Behavior Karyawan PT. Perkebunan Nusantara XIV }\end{array}$ \\
\cline { 2 - 7 } Variabel & $\mathbf{R}$ & $\begin{array}{c}\text { R } \\
\text { Square }\end{array}$ & Konstanta & $\begin{array}{c}\text { Koef. } \\
\text { Regresi }\end{array}$ & Sig. & $\boldsymbol{\alpha}$ \\
\hline Kepuasan Kerja & - & 0.302 & 17.844 & 0.629 & 0.000 & 0,05 \\
\hline Pengujian Signifikansi & & & & & \\
\hline t hitung > t tabel = 6.244 > 1.661 & & & & \\
\hline
\end{tabular}

Keterangan: Variabel Organizational Citizenship Behavior

Sumber: Data diolah 2021

Tabel 2, nilai koefisien determinasi $\left(\mathrm{R}^{2}\right)$ sebesar 0.302, artinya kepuasan kerja memberikan kontribusi sebesar 30,2\% kepada organizational citizenship behavior karyawan PT. Perkebunan Nusantara XIV, sedangkan sisanya sebesar $69,8 \%$ disumbangkan faktor lain yang tidak diteliti.

Persamaan regresi $\mathrm{Y}=17,844+0,629$ $\mathrm{X}_{1}$.
Kepuasan kerja berpengaruh positif dan signifikan pada tingkat nyata $99 \%$ terhadap organizational citizenship behavior karyawan PT. Perkebunan Nusantara XIV. Koefisien kepuasan kerja sebesar 0,629, artinya jika ada peningkatan kepuasan kerja, maka organizational citizenship behavior karyawan PT. Perkebunan Nusantara XIV akan meningkat atau sebaliknya.

Tabel 3: Pengaruh Lingkungan Kerja terhadap Organizational Citizenship Behavior Karyawan PT. Perkebunan Nusantara XIV

\begin{tabular}{ccccccc}
\hline \multirow{2}{*}{ Variabel } & \multicolumn{7}{c}{ Parameter } \\
\cline { 2 - 7 } & $\mathbf{R}$ & $\begin{array}{c}\mathbf{R} \\
\text { Square }\end{array}$ & Konstanta & Koef. Regresi & Sig. & $\boldsymbol{\alpha}$ \\
\hline Lingkungan Kerja & - & 0.154 & 22.197 & 0.498 & 0.000 & 0,05
\end{tabular}

\section{Pengujian Signifikansi}

t hitung $>\mathrm{t}$ tabel $=4,043>1.661$

\section{Keterangan: Variabel Organizational Citizenship Behavior}

Sumber: Data diolah2021

Tabel 3, nilai koefisien determinasi $\left(\mathrm{R}^{2}\right)$ sebesar 0.154 , artinya lingkungan kerja memberikan kontribusi sebesar 15,4\% kepada organizational citizenship behavior karyawan PT. Perkebunan
Nusantara XIV, sedangkan sisanya sebesar $84,6 \%$ disumbangkan faktor lain yang tidak diteliti.

Persamaan regresi $\mathrm{Y}=22,197+0,498$ $\mathrm{X}_{2}$. 
Lingkungan kerja berpengaruh positif dan signifikan pada tingkat nyata 99\% terhadap organizational citizenship behavior karyawan PT. Perkebunan Nusantara XIV. Koefisien lingkungan kerja sebesar 0,498, artinya jika ada peningkatan lingkungan kerja maka organizational citizenship behavior karyawan PT. Perkebunan Nusantara XIV akan meningkat atau sebaliknya.

\section{Analisis regresi linear berganda}

Tabel 4: Pengaruh Kepuasan Kerja dan Lingkungan Kerja terhadap Organizational Citizenship Behavior Karyawan PT. Perkebunan Nusantara XIV

\begin{tabular}{|c|c|c|c|c|c|c|}
\hline \multirow[b]{2}{*}{ Variabel } & \multicolumn{6}{|c|}{ Parameter } \\
\hline & $\begin{array}{c}\text { Mult } \\
\text {. R }\end{array}$ & $\begin{array}{c}\mathbf{R} \\
\text { Square } \\
\end{array}$ & Konstanta & $\begin{array}{c}\text { Koef. } \\
\text { Regresi }\end{array}$ & Sig. & $\alpha$ \\
\hline $\begin{array}{l}\text { Kepuasan Kerja } \\
\text { Ling_Kerja }\end{array}$ & - & 0.342 & 10.352 & $\begin{array}{l}0.536 \\
0.273\end{array}$ & $\begin{array}{l}0.000 \\
0.023\end{array}$ & 0,05 \\
\hline
\end{tabular}

Pengujian Signifikansi

Signifikan Probability 0.000

\section{Keterangan: Variabel Organizational Citizenship Behavior}

Sumber: Data diolah 2021

Berdasarkan tabel 4, signifikan probability 0,000 lebih kecil dari alpha 0,05 , artinya kepuasan kerja dan lingkungan kerja secara bersama-sama berpengaruh signifikan terhadap organizational citizenship behavior karyawan PT. Perkebunan Nusantara XIV. Koefisien Determinasi $\left(\mathrm{R}^{2}\right)$ yaitu 0,342 atau sebesar $34,2 \%$. Kontribusi kepuasan dan lingkungan kerja kepada organizational citizenship behavior, sedangkan sisanya $65,8 \%$ disumbangkan oleh variabel lain yang tidak disertakan dalam penelitian ini.

Persamaan regresi linier berganda sebagai berikut: $\mathrm{Y}=10,352+0,536 \mathrm{X}_{1}+$ $0,273 \mathrm{X}_{2}$

Kepuasan kerja dan Lingkungan kerja berpengaruh positif dan signifikan terhadap organizational citizenship behavior PT. Perkebunan Nusantara XIV pada tingkat nyata 99\%. Koefisien kepuasan kerja sebesar 0,536 artinya jika ada peningkatan kepuasan kerja, maka organizational citizenship behavior PT. Perkebunan Nusantara XIV akan meningkat atau sebaliknya dengan asumsi lingkungan kerja tidak berubah. Koefisien lingkungan kerja sebesar 0,273, artinya jika ada peningkatan lingkungan kerja, maka organizational citizenship behavior PT. Perkebunan Nusantara XIV akan meningkat atau sebaliknya, dengan asumsi kepuasan kerja tidak berubah

\section{Pembahasan}

Pengaruh Kepuasan Kerja terhadap Organizational Citizenship Behavior pada karyawan PT. Perkebunan Nusantara XIV .

Berdasarkan hasil penelitian ditemukan bahwa semakin tinggi kepuasan kerja maka akan meningkatkan organizational citizenship behavior karyawan PT. Perkebunan Nusantara XIV. Hal ini dikarenakan manajemen perusahaan sudah memberikan apa yang telah diharapkan oleh karyawan itu sendiri seperti gaji yang memadai, 
promosi karyawan yang berprestasi, pengawasan yang baik, rekan kerja yang baik, dan lainnya. Hasil ini senada dengan penelitian yang dilakukan oleh Rohayati (2014), Nurhayati, et al. (2016), Waspodo, et al (2019) yang menemukan bahwa ada pengaruh positif dan signifikan kepuasan kerja terhadap organizational citizenship behavior.

\section{Pengaruh Lingkungan Kerja terhadap Organizational Citizenship Behavior pada karyawan PT. Perkebunan Nusantara XIV .}

Berdasarkan hasil penelitian ini ditemukan bahwa perbaikan lingkungan kerja akan mendorong meningkatkan organizational citizenship behavior karyawan PT. Perkebunan Nusantara XIV. Hal ini dikarenakan lingkungan kerja fisik dan lingkungan kerja non fisik yang ada di PT. Perkebunan Nusantara XIV cukup memadai, sehingga organizational citizenship behavior meningkat. Hasil ini senada dengan penelitian yang dilakukan oleh Febytama (2018), Nurhayati, et al, (2016), Waspodo, et al, (2019) yang menemukan bahwa ada pengaruh positif dan signifikan lingkungan terhadap Organizational Citizenship Behavior.

Pengaruh Kepuasan dan Lingkungan Kerja terhadap Organizational Citizenship Behavior pada karyawan PT. Perkebunan Nusantara XIV.

Berdasarkan hasil penelitian ini ditemukan bahwa peningkatan kepuasan kerja dan perbaikan lingkungan kerja akan meningkatkan organizational citizenship behavior karyawan PT. Perkebunan Nusantara XIV. Hasil ini senada dengan penelitian yang dilakukan Nurhayati, et al, (2016), Waspodo, et a,l (2019) yang menemukan bahwa secara bersama sama kepuasan kerja dan lingkungan kerja berpengaruh positif dan signifikan terhadap organizational citizenship behavior.

\section{KESIMPULAN DAN SARAN}

\section{Kesimpulan}

Kepuasan kerja mendorong peningkatan organizational citizenship behavior karyawan PT. Perkebunan Nusantara XIV. Hal ini berarti apabila kepuasan kerja yang dirasakan karyawan dalam bekerja meningkat maka akan meningkatkan pula organizational citizenship behavior karyawan PT. Perkebunan Nusantara XIV.

Lingkungan kerja mendorong peningkatan organizational citizenship behavior karyawan PT. Perkebunan Nusantara XIV. Hal ini berarti apabila lingkungan kerja perusahaan baik fisik maupun non fisik semakin kondusif maka akan meningkatkan pula organizational citizenship behavior karyawan PT. Perkebunan Nusantara XIV.

Kepuasan kerja dan lingkungan kerja secara bersama sama mendorong peningkatan organizational citizenship behavior karyawan PT. Perkebunan Nusantara XIV. Hal ini menunjukkan bahwa semakin tinggi kepuasan kerja dan lingkungan kerja karyawan PT. Perkebunan Nusantara XIV.

\section{Saran}

Manajemen PT. Perkebunan Nusantara XIV perlu lebih meningkatkan dan mengutamakan kondisi lingkungan kerja terutama pada kondisi bangunan dan pewarnaan dan kenyamanan karyawan.

Penelitian ini menggunakan dua variabel bebas untuk mengukur organizational citizenship behavior, sehingga disarankan bagi penelitian selanjutnya untuk mengembangkan dengan variabel lainnya yang lebih relevan yang memiliki pengaruh terhadap organizational citizenship behavior karyawan, sehingga dapat membantu tercapainya tujuan PT. Perkebunan Nusantara XIV. 


\section{DAFTAR PUSTAKA}

Colquitt, J. A., Lepine, A. J., \& Wesson, J. M. 2011. Organizational Behavior. New York: Mc. Graw Hill

Febytama. Rerynda Dita. 2018. Pengaruh Lingkungan Kerja terhadap Organizational Citizenship Behavior melalui Komitmen pada karyawan PT. Pos Indonesia Kantor Pusat Malang. http://karyailmiah.um.ac.id/index.p hp/manajemen/issue/archive

Luthans, F. 2005. Organizational Behavior. New York: McGraw-hill.

Mangkunegara. A.A. Anwar Prabu 2017. Manajemen Sumber Daya Manusia. Perusahaan, Bandung: Remaja Rosdakarya

Nurhayati Diah, Minarsi., Maria Magdalena dan Wulan, Heru sri. 2016 Pengaruh Kepuasan Kerja, Lingkungan Kerja dan Loyalitas Kerja Tehadap Organizational Citizenship Behavior (Studi Kasus Pada PT. Perwirabhakti Sentra Sejahtera Di Kota Semarang) Journal of Management, Volume 2 No. 2 Maret 2016

Organ, D. W. 2015. Organizational Citizenship Behavior. In International Encyclopedia of the Social \& Behavioral Sciences (2nd ed., pp. 317-321). Elsevier Ltd.

Podsakoff, P., MacKenzie, S. B., Paine, J. B., \& Bachrah, D. G. 2000. Organizational citizenship behaviors: a critical review of the theoretical and empirical literature and suggestions for future research. Journal of Management, 26 (3), 513-563. https://doi.org/ 10.1016/S0149-2063(00)00047-7
Robbins, Stephen (2015), Perilaku Organisasi. Jakarta: Penerbit Salemba Empat.

Rohayati Ai. 2014 Pengaruh Kepuasan Kerja Terhadap Organizational Citizenship Behavior: Studi Pada Yayasan Masyarakat Madani Indonesia. SMART - Study \& Management Research | Vol XI, No. 1 - 2014

Swaminathan, Samanvitha. 2013. Job Satisfaction as a Predictor Of Organizational Citizenship Behavior: An Empirical Study. Global Journal of Business Research, Vol. 7 (1), 71-80. Retrieved from Social Science Research Network Journal Database

Sedarmayanti. 2017. Manajemen Sumber Daya Manusia. Bandung: Refika. Aditama.

Sukmawati, Thoyib Armanu, Surachman. 2013. Peran Organizatonal Citizenship Behavior sebagai Mediator Pengaruh Kepuasan Kerja, Lingkungan Kerja dan Komitmen Organisasi Terhadap Kinerja Karyawan, Jurnal Aplikasi Manajemen, Volume Sebelas.

Sutrisno, Edy, 2016, Manajemen Sumber Daya Manusia. Jakarta: Kencana Prenada. Media Group.

Waspodo, Lindawati dan Sholikhah. 2019. Pengaruh Kepuasan Kerja Dan Lingkungan Kerja Terhadap Organizational Citizenhip Behavior Karyawan Perum Damri Kantor Pusat. Jurnal Riset Manajemen Sains Indonesia (JRMSI) | Vol 10, No. 1, 2019 